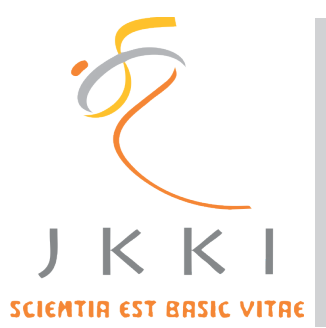

Jurnal Kedokteran dan Kesehatan Indonesia

Indonesian Journal of Medicine and Health

Journal homepage : www.journal.uii.ac.id/index.php/jkki

\title{
The expression of multidrug resistance protein 5 and thymydilate synthase on fluorouracil resistance WiDr colon cancer cell line
}

Yolanda Dyah Kartika ${ }^{1}$, Indwiani Astuti ${ }^{1}$, Woro Rukmi Pratiwi ${ }^{1}$

${ }^{1}$ Department of Pharmacology and Therapy, Faculty of Medicine, Universitas Gadjah Mada

Original Article

\section{ABSTRACT}

ARTICLE INFO

\section{Keyword:}

Fluorouracil

resistance

WiDr

MRP5

Thymydilate Synthase

*Corresponding author: yolandadyahkartika@ugm.ac.id
Background: Colorectal cancer becomes one of the most common cancer in Indonesia. Fluorouracil is an essential drug in colorectal cancer therapy as it has been supplemented in about $69 \%$ of current regiments of chemotherapy. However, drug resistance has reduced its clinical applications. Many factors that contribute to fluorouracil resistance have been investigated including overexpression of Multidrug Resistance Protein 5 (MRP 5) and high level expression of Thymidylate Synthase (TS). Therefore, the expression of those proteins may become key indicators to predict the presence of resistance in the model of fluorouracil-resistance-WiDr colon cancer cell line.

Objective: The aim of this study is to characterize a 5-FU acquired resistance WiDr colon cancer cell line, focus on the expression of MRP5 and TS.

Methods: This study was a post test controlled group design. The expression of MRP5 and TS were analyzed using immunocytochemistry method. Before protein expression analysis, 4 groups of WiDr colon cancer cell line, group 1, 2, 3, and 4 (control) were treated with 4 different concentration of fluorouracil $12.3 \mu \mathrm{M}, 6.15 \mu \mathrm{M}, 3.08 \mu \mathrm{M}$, and $0 \mu \mathrm{M}$ respectively. Previous study showed that a significant increased level of IC50 value is observed in group induced with fluorouracil 3.08 $\mu \mathrm{M}$ (group 3). Statistical tests for protein expression performed with SPSS version 19 using Kruskall Wallis with 95\% confidence level (p $<0.05$ ).

Results: The expression of MRP5 and TS in the group developed fluorouracil resistance (group 3) were significantly increased compared to control group $(\mathrm{p}<0.05)$. In contrast, the other group exposed with higher dose of fluorouracil did not show both significant increased level of IC50 nor significant different of MRP5 and TS expression compared with the control group.

Conclusion: The model of fluorouracil-acquired resistant WiDr cell line expresses Thymidilate Synthase and Multidrug Resistance Protein 5. The expressions of these proteins are in accordance with the profile of fluorouracil resistancy. 
Latar belakang: Kanker kolorektal merupakan salah satu kanker yang sering ditemui di Indonesia. Fluorouracil (5-FU) merupakan obat yang esensial dalam terapi kanker tersebut. Fluorouracil disuplementasikan pada sekitar 69\% dari seluruh regimen kemoterapi yang ada saat ini. Namun obat ini mulai terbatas aplikasi klinisnya dikarenakan adanya resistensi obat. Terdapat beberapa faktor yang berkontribusi pada proses terjadinya resistensi, antara lain Multidrug Resistance Protein 5 dan Thymydilate Synthase. Ekspresi kedua protein tersebut dapat menjadi indikator kunci terjadinya resistensi pada model sel kanker WiDr yang telah dibuat resisten terhadap fluorouracil.

Tujuan: Penelitian ini bertujuan untuk mengetahui karakteristik model kanker kolon sel line WiDr resisten 5-FU terutama dalam hal ekspresi Multidrug Resistance Protein 5 dan Thymydilate Synthase.

Metode: Penelitian ini merupakan posttest controlled group design. Uji imunositokimia dilakukan untuk melihat adanya ekspresi protein MRP5 dan TS. Sebelum dilakukan analisa protein, telah dikembangkan 4 kelompok sel line WiDr, yakni kelompok 1, 2, 3, dan 4 yang masing-masing dipapar dengan 4 konsentrasi fluorouracil 12.3 $\mu M, 6.15 \mu M, 3.08 \mu M$, dan $0 \mu M$. Studi sebelumnya menunjukkan bahwa peningkatan IC50 yang signifikan terjadi pada kelompok yang diberi paparan fluorouracil $3.08 \mu \mathrm{M}$ (kelompok3). Analisis statistic menggunakan SPSS 19. Uji statistik yang digunakan adalah uji Kruskall Wallis untuk analisis ekspresi protein dengan interval kepercayaan 95\% $(p<0.05)$

Hasil: Ditemukan nilai ekspresi MRP5 dan TS yang meningkat secara signifikan pada kelompok sel line WiDr yang resisten terhadap fluorouracil $(p<0.05)$. Tidak didapatkan kenaikan ekspresi MRP5 dan TS yang signifikan pada kelompok yang tidak mengalami resistensi fluorouracil

Kesimpulan: Model sel line kanker kolon WiDryang resisten terhadap 5-FU mengekspresikan protein Thymidilate Synthase dan Multidrug Resistance Protein 5. Ekspresi protein tersebut berhubungan dengan profil resistensi sel terhadap fluorouracil.

\section{INTRODUCTION}

Colorectal cancer becomes one of the most common cancer in Indonesia. World Health Organization has reported about 17,326 cases in men and 16,413 cases in women, causing 25,253 for total mortality. ${ }^{1-2}$ Nowadays, fluorouracil becomes an essential drug in colorectal cancer therapy as it has been supplemented in about $69 \%$ of current regiments chemotherapy for colon cancer3. Drug resistance has reduced its clinical applications however. Fluorouracil resistance has frequently existed in the treatment of digestive tract cancer. ${ }^{4-5}$

Fluorouracil generates cytotoxicity by building a stable complex with thymidylate synthase (TS). This complex, thereafter, inhibits deoxythimidine monophosphate (dTMP) synthesis. The reduction of dTMPs then followed by downstream depletion of deoxythimidine triphosphate (dTTP) which essential for DNA replication and repair. ${ }^{6}$

Many factors that contribute to fluorouracil resistance have been investigated including overexpression of Multidrug Resistance Protein 5 (MRP5/ABCC5) and high level expression of thymidylate synthase (TS). ${ }^{7}$ Multidrug Resistance Protein 5 is a family of $\mathrm{ABC}$ transporter and localized in the basolateral membrane of duodenum, terminal ileum, and all sites of the colon. ${ }^{8}$ Multidrug Resistance Protein 5 mediates the efflux of fluorouracil metabolites including 5-FdUMP, 5-FUMP, and dUMP out from the cell, thus, causes 9-fold resistance to 5-FU6. The other protein, Thymidylate Synthase, is a key enzyme in DNA synthesis and becomes a target enzyme of 5-FU to induce inhibitory effect of DNA synthesis. Therefore, high levels of TS will also predict resistance. ${ }^{9}$

To develop a new strategy against drug resistance, a model of fluorouracil resistance WiDr colon cancer cell line has been developed previously. ${ }^{10}$ The aim of this study is to evaluate the expression of proteins responsible for fluorouracil resistance, MRP5 and TS, expressed in that fluorouracil-resistance WiDr colon cancer model.

\section{METHODS \\ Materials}

ABCAM (M5II-54) rat monoclonal antibody anti MRP5, Starr Trek HRP-DAB (Biocare), primary mouse anti-TS human antibody (clone TS106, Zymed), DMEM medium, Fetal bovine serum, trypsin, penicillin-streptomisin, amphotericin, Complete medium (FBS 10ml + penicillin-streptomisin $2 \mathrm{ml}+$ Amphotericine 0.5 
$\mathrm{ml}+$ DMEM medium ad to $100 \mathrm{ml}$ ), PBS, MTT solution, Sodium dodesil sulphate.

Adenocarcinoma cell line WiDr was obtained from Chemotherapy and Chemoprevention Research Centre, Faculty of Pharmacy, Gadjah Mada University. The models of fluorouracilresistance WiDr colon cancer cell line had been developed previously by giving 5 intermittent fluorouracil exposures as described previously. ${ }^{10}$ Briefly, before protein expression analysis, 4 groups of WiDr colon cancer cell line, group $1,2,3$, and 4 (control) were treated with 4 different concentration of fluorouracil $12.3 \mu \mathrm{M}$, $6.15 \mu \mathrm{M}, 3.08 \mu \mathrm{M}$, and $0 \mu \mathrm{M}$ respectively in 5 cycles. Previous study showed that a significant increased level of $\mathrm{IC}_{50}$ value is observed in group induced with fluorouracil $3.08 \mu \mathrm{M}$ (group 3). ${ }^{10}$ Cells were considered as resistance if its $5-\mathrm{FU} \mathrm{IC}_{50}$ post exposure increases significantly compared with 5 -FU IC ${ }_{50}$ of the parental cells. ${ }^{11}$

Thereafter, in this study, the expression of Multidrug Resistance Protein 5 and Thymydilate Synthase were analyzed from all of those groups of WiDr colon cancer cell line models.

\section{Immunocytochemistry analysis of Multidrug Resistance Protein 5 expression}

The MRP5 expression was analyzed using immunocytochemistry (ICC) method. Cells were considered as positive when immunological reaction is present in the membrane of the cell. It was a modification from previous method. ${ }^{12}$ After the cultured cells were fixed in cold methanol, endogenous peroxidase blocker was added and the cells were incubated for 20 minutes, and then rinsed with deionized water. The slides then were flood with PBS wash buffer. The slide was drained before of protein blocker were added for 5-10 minutes. After incubation, protein blocker was drained before the ABCAM (M5II-54) rat monoclonal antibody (1:20 dilution) was added and incubated 60 minutes. The slide was washed again with PBS. Afterwards, the cells were treated with anti-mouse antibody for 10 minutes, followed by PBS wash buffer 2 times. This procedure then was followed by addition of DAB chromogen/substrate 3-5 minutes at room temperature. The slides were washed again using deionized water before counterstained with hematoxilin for 45 minutes. The analysis was performed in duplicate.

\section{Statistic Analysis}

All of the statistical analyses were performed using statistical program SPSS 19. To assess the extent of MRP 5 and TS expressions in colon cell line WiDr resistance to $5-\mathrm{FU}$, the percentage of the positive cells in each treatment group were compared to positive cells in control group using Kruskall Wallis with 95\% confidence level (p $<0.05)$.

\section{RESULTS}

Multidrug Resistance Protein 5 Expression

The expression of Multidrug Resistance Protein 5 was increased in group 3 (Figure 1). From the statistical analysis, we found that the increased level of MRP5 in group 3 was statistically significant compared to group 4 (control group) $(\mathrm{p}<0.05)$ (Table 1). In contrast, the other groups that were not developed fluorouracil resistance did not show significant increase of MRP5 expression compared to the control group.

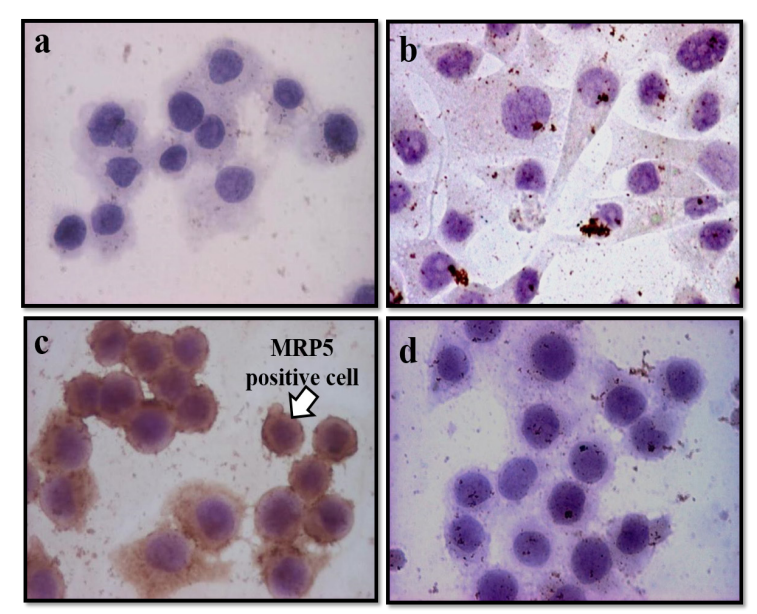

Figure 1 The expression of Multidrug Resistance Protein 5 in WiDr cell line of each group after various concentration of fluorouracil exposure. These slides were observed using magnification 400x. a. MRP5 expression in group 1, b. MRP5 expression in group 2, c. MRP5 expression in group 3, d. MRP5 expression in group 4 (control). 
Table 1 Mean percentage of MRP5 positive cells on WiDr cell line after various concentration of fluorouracil exposure.

\begin{tabular}{cccc}
\hline Group & $\begin{array}{c}{[5-\mathrm{FU}]} \\
\text { exposure } \\
(\mu \mathrm{M})\end{array}$ & $\begin{array}{c}\text { Mean percentage } \\
\text { of MRP5 positive } \\
\text { cells (Mean } \pm \text { SD) }\end{array}$ & ICC $^{ \pm}$ \\
\hline 1 & 12.3 & $0.45 \pm 0.64$ & \\
2 & 6.15 & $0.0 \pm 0.0$ & 0.999 \\
3 & 3.075 & $31.77 \pm 0.23^{*}$ & \\
4 & control & $0.0 \pm 0.0$ & \\
\hline
\end{tabular}

${ }^{*} \mathrm{p}<0.05$, compared to control group

Intraclass correlation

\section{Thymydilate Synthase Expression}

The expression of Thymydilate Synthase was increased in group 2 and 3 (Figure 2). However, statistic analysis found that the significant increased level of Thymydilate Synthase was only found in group $3(\mathrm{p}<0.05)$ (Table 2$)$. There was no significant increase of TS expression on the other groups that were not developed fluorouracil resistance.

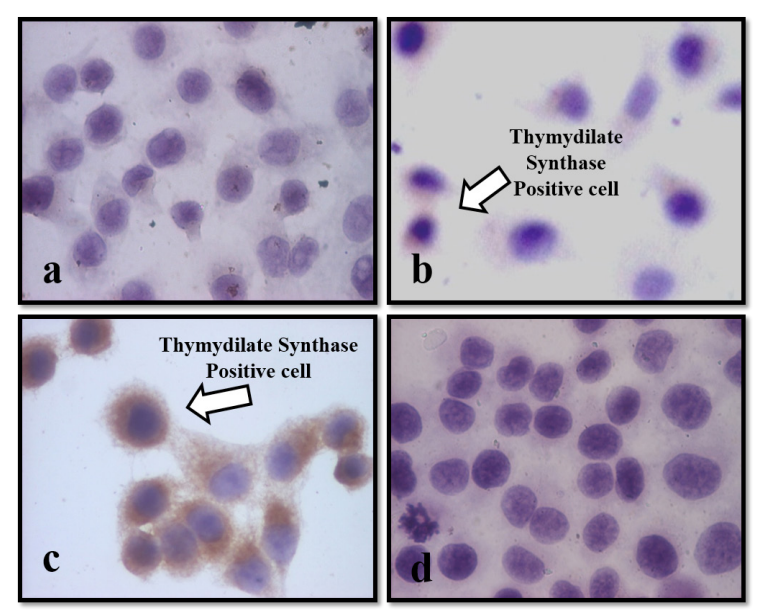

Figure 2 The expression of Thymydilate Synthase in WiDr cell line of each group after various concentration of fluorouracil exposure. These slides were observed using magnification 400x a. TS expression in group $1 ; \mathrm{b}$. TS expression in group 2; c. TS expression in group 3; d. TS expression in group 4 (control).
Table 2 Mean percentage of Thymydilate Synthase (TS) positive cells on WiDr cell line after various concentration of fluorouracil exposure.

\begin{tabular}{cccc}
\hline Group & $\begin{array}{c}{[5-\mathrm{FU}]} \\
\text { exposure } \\
(\mu \mathrm{M})\end{array}$ & $\begin{array}{c}\text { Mean percentage } \\
\text { of MRP5 positive } \\
\text { cells (Mean } \pm \text { SD })\end{array}$ & ICC $^{ \pm}$ \\
\hline 1 & 12.3 & $0.0 \pm 0.0$ & \\
2 & 6.15 & $5.86 \pm 0.08$ & 0.994 \\
3 & 3.075 & $67.27 \pm 0.99^{*}$ & \\
4 & control & $0.0 \pm 0.0$ & \\
\hline
\end{tabular}

${ }^{*} \mathrm{p}<0.05$, compared to control group

${ }^{\mathrm{f}}$ Intraclass correlation

\section{DISCUSSION}

Resistance to 5-FU chemotherapy is a key problem in colon cancer therapy and can be induced by several factors. The process of chemoresistance development in the tumors itself can be mediated by various cellular mechanisms including low drug concentration at the intracellular target sites and overexpression of target protein. ${ }^{14}$

ATP-binding cassette $(\mathrm{ABC})$ transporters family are known to be responsible in the development of resistance by the efflux of anticancer agents outside of cancer cells and causing low drug concentration at the cells. ${ }^{15}$ Multidrug Resistance Protein 5 is one of the $\mathrm{ABC}$ transpoters family which may reduce 5-FU level intracellular by mediating transport of 5-Fluorouridine-5-Monophosphate (5FUMP) out from the cell. One of the substance, 5-Fluorouridine-5-Monophosphate, is a metabolite of 5-FU that will be converted into 5-FUTP and leading to RNA incorporation. ${ }^{6}$ The decreased level of 5-FUMP lead to depletion of 5-FUTP and finally could lead to the reduction of RNA incorporation. Moreover, the exposure of 5-FU could induce the expression of Multidrug Resistance Protein 5. ${ }^{16}$

In this study, the significant increased of the Multidrug Resistance Protein 5 expression in fluorouracil-resistance WiDr cell line models indicates that MRP5 expression correlates with the profile of fluorouracil resistancy. The data (Table 1) showed that the expression of MRP5 only found in group that developed fluorouracil resistance. The modulation of MRP5 expression 
using drug exposure also found in another study employing another cell line as the sample. ${ }^{13-14}$ The expression of MRP5 in adriamycin resistancehuman cancer cell line could be induced after 1 exposure of drug to the cell. ${ }^{17}$

Thymydilate Synthase is a target protein of fluorouracil. It plays a crucial role the process of DNA synthesis. The cytotoxic effect of fluorouracil is mainly generated from the inhibition of this protein. The induction of Thymydilate Synthase expression can be obtained by repeated 5-FU exposure. The results of this study represent that the expression of Thymydilate Synthase can be found only in group that develop fluorouracil resistance. The significant correlation between TS expression and the IC50 value of the cells indicates that TS contributes in the development of fluorouracil-acquired resistance (Table 2).

This study is relevant with previous study that showed an overexpression of Thymydilate Synthase in 5-FU resistance cell line after 6th fluorouracil exposure. ${ }^{18}$ In clinical setting, the expression of Thymydilate Synthase increases since the first 48 hours after initial administration of fluorouracil. ${ }^{19}$

Overall, this study suggests that the expression of Multidrug Resistance Protein 5, in accordance with Thymidilate Synthase, will be found in the model of fluorouracil resistance WiDr colon cancer cell line. These data support the concept that the mechanism of fluororuracil resistance in WiDr colon cancer line is likely related with the expression of these proteins.

\section{CONCLUSIONS}

The model of 5-FU-acquired resistant WiDr cell line expresses Thymidilate Synthase and Multidrug Resistance Protein 5 after 5 intermitten 5-FU exposures. The profile of protein expression correlates with the profile of fluorouracil resistancy.

Further study with intermittent analysis should be done to analyze the possibility of the time dependent manner of the MRP5 and TS expression in the fluorouracil resistance WiDr colon cancer model.

\section{ACKNOWLEDGEMENT}

This study was supported by funding from
Biro Pendidikan dan Kerjasama Luar Negeri. We thank to Mrs. Rumbiwati and Mrs. Juanna Nursanti for their technical support.

\section{REFERENCES}

1. Bray F, Ren JS, Masuyer E, Ferlay J. Estimates of global cancer prevalence for 27 sites in the adult population in 2008. Int J Cancer 2012 Jul 3;doi:10.1002/ijc.27711.

2. Ferlay J, Shin HR, Bray F, Forman D, Mathers C, Parkin DM. GLOBOCAN 2008 v1.2, Cancer Incidence and Mortality Worldwide IARC CancerBase No. 10 [Internet]. Lyon, France: International Agency for Research on Cancer 2010 [cited 2011 Oct 25];Available from: URL: http://globocan.iarc.fr

3. Gill S, Blackstock AW, Goldberg RM. Colorectal Cancer. Mayo Clin Proc 2007 p. 114-29.

4. Douillard JY, Cunningham D, Roth AD, Navarro M, James RD, Karasek P, et al. Irinotecan combined with fluorouracil compared with fluorouracil alone as first-line treatment for metastatic colorectal cancer: a multicentre randomised trial. Lancet 2000;355(9209):1041-7.

5. Ohtsu A, Shimada Y, Shirao K, Boku N, Hyodo I, Saito H, et al. Randomized Phase III Trial of Fluorouracil Alone Versus Fluorouracil Plus Cisplatin Versus Uracil and Tegafur Plus Mitomycin in Patients With Unresectable, Advanced Gastric Cancer: The Japan Clinical Oncology Group Study (JCOG9205). J Clin Oncol 2003;21(1):54-9.

6. Pratt S, Shepard RL, Kandasamy RA, Johnston PA, Perry W, Dantzig AH. The multidrug resistance protein 5 (ABCC5) confers resistance to 5-fluorouracil and transports its monophosphorylated metabolites. Mol Cancer Ther 2005;4(5):855-63.

7. Zhang N, Yin Y, Xu SJ, Chen WS. 5-Fluorouracil: Mechanisms of Resistance and Reversal Strategies. Molecules 2008;13(8):1551-69.

8. Sugunan SLC. Pharmacogenetics of Doxorubicin in Asian Breast Cancer Patients National University of Singapore, Singapore.; 2008.

9. Aschele C, Debernardis D, Casazza S, Antonelli G, Tunesi G, Baldo C, et al. Immunohistochemical quantitation of thymidylate synthase expression in colorectal cancer 
metastases predicts for clinical outcome to fluorouracil-based chemotherapy. J Clin Oncol 1999;17(6):1760-70.

10. Kartika YD, Astuti I, Pratiwi WR. Development of a 5-Fluorouracil Acquired Resistance WiDr Colon Cancer cell line, paper presented at Opportunities and Challenges of Traditional Medicine in Formal Health Services Conference, Yogyakarta, March 15, 2014 page 284-8.

11. Subbarayan, P.R., Sarkar, M., Nelson, G., Benitez, E., Singhal, S., \& Ardalan, B. Chronic exposure of colorectal cancer cells in culture to fluoropyrimidine analogs induces thymidylate synthase and suppresses p53. A molecular explanation for the mechanism of 5-FU resistance. Anticancer Res. 2010;30(4):1149-1156.

12. Karla, P.K., Quinn, T.L., Herndon, B.L., Thomas, P., Pal, D., \& Mitra, A. Expression of multidrug resistance associated protein 5 (MRP5) on cornea and its role in drug efflux. J Ocul Pharmacol Ther. 2009;25(2):121-132.

13. Ceppi, P., Volante, M., Ferrero, A., Righi, L., Rapa, I., Rosas, R., Berruti, A., Dogliotti, L., Scagliotti, G.V., \& Papotti, M. Thymidylate synthase expression in gastroenteropancreatic and pulmonary neuroendocrine tumors. Clin Cancer Res. 2008;14(4):1059-1064.

14. Hagmann W, Jesnowski R, Faissner R, Guo $\mathrm{C}$, Löhr JM. ATP-binding cassette C transporters in human pancreatic carcinoma cell lines. Upregulation in 5-fluorouracil-resistant cells. Pancreatology 2009;9(1-2):13644.

15. Hlavata I, Mohelnikova-Duchonova B, Vaclavikova R, Liska V, Pitule P, Novak P, et al. The role of $\mathrm{ABC}$ transporters in progression and clinical outcome of colorectal cancer. Mutagenesis 2012;27(2):187-196..

16. Nambaru $P K$, Hübner $T$, Köck $K$, Mews $S$, Grube M, Payen L, et al. Drug efflux transporter MRP5 affects sensitivity of pancreatic cancer cell lines to the nucleoside anticancer drug 5-fluorouracil. Drug Metab Dispos 2011;39(1):132-9.

17. Yoshida M, Suzuki K, Komiya T, Hatashita E, Nishio K, Kazuhiko N, et al. Iinduction of MRP5 and SMRP mRNA by Adriamycin Ex- posure and its Overexpression in Human Lung Cancer Cells Resistant to Adriamycin. Int J Cancer 2001;94:432-7.

18. Sigmond J, Backus HH, Wouters D, Temmink $\mathrm{OH}$, Jansen G, Peters GJ. Induction of Resistance to the Multitargeted Antifolate Pemetrexed (ALIMTA) in WiDr Human Colon Cancer Cells is Associated with Thymidilate Synthase Overexpression. Biochem Pharmacol 2003;66(3):-431.

19. Mauritz R, van Groeningen CJ, Smid K, Jansen K, Pinedo HM, Peters GJ. Thymidylate synthase and dihydropyrimidine dehydrogenase mRNA expressionn after administration of 5-fluorouracil to patients with colorectal cancer. Int. J. Cancer: 120, 2609-12. Int J Cancer 2007;120(12):2609-12. 